\title{
Dexamethasone Inhibits Human Interleukin 2 but Not Interleukin 2 Receptor Gene Expression In Vitro at the Level of Nuclear Transcription
}

\author{
Dimitrios T. Boumpas, Evangelos D. Anastassiou, Steven A. Older, George C. Tsokos, David L. Nelson, ${ }^{\star}$ and James E. Balow \\ Kidney Disease Section, National Institute of Diabetes and Digestive and Kidney Diseases, and *Immunobiology Section, \\ National Cancer Institute, National Institutes of Health, Bethesda, Maryland 20892
}

\begin{abstract}
Glucocorticosteroids have an inhibitory effect on the expression of interleukin 2 (IL-2) and interleukin 2 receptor (IL-2R) genes. To determine the mechanisms of this inhibition, human $T$ lymphocytes were stimulated with mitogens in the presence of dexamethasone. Nuclear transcription run-off assays showed that high doses of dexamethasone inhibited the transcription of the IL-2 gene but not that of the IL-2R gene. Posttranscriptionally, high doses of dexamethasone $\left(10^{-4} \mathrm{M}\right)$ were required to inhibit IL-2R mRNA levels by $50 \%$, whereas lower doses $\left(10^{-6} \mathrm{M}\right)$ inhibited by $>70 \%$ the accumulation of IL-2 mRNA. IL-2 mRNA half-life decreased in the presence of dexamethasone $\left(10^{-6} \mathrm{M}\right)$ by $\sim 50 \%$. At the protein product level, dexamethasone inhibited both IL-2 production, as well as cell surface and soluble forms of IL-2R. IL-2R gene expression was inhibited for at least $72 \mathrm{~h}$ after exposure of cells to dexamethasone. In the presence of exogenous IL-2, dexamethasone failed to exert a significant effect on the production of $I L-2 R$ protein. These data indicate that dexamethasone has a greater effect on the expression of the IL-2 gene than on the IL-2R gene. Dexamethasone both inhibits transcription of the IL-2 gene and decreases the stability of IL-2 mRNA. The effect of dexamethasone on the IL-2R gene is post-transcriptional and may result indirectly from decreased IL-2 production. (J. Clin. Invest. 1991. 87:1739-1747.) Key words: corticosteroids • gene regulation • glucocorticosteroids • messenger RNA • messenger RNA stability
\end{abstract}

\section{Introduction}

Stimulation of $\mathrm{T}$ cells by antigens or mitogens leads to synthesis of interleukin 2 (IL-2) and receptors for IL-2 (IL-2R) ${ }^{1}$ (1). After activation with phytohemagglutinin (PHA), the number of IL-2R peaks within 48-72 $\mathrm{h}$ and then declines. This rise and fall in IL-2R gene expression is paralleled by changes in $T$ cell proliferation. Thus, the regulation of both IL- 2 and IL-2R gene expression is critically involved in the control of $\mathrm{T}$ cell growth and the normal immune response $(1,2)$.

High-affinity IL-2R have been found to consist of two dis-

Address reprint requests to Dr. Boumpas, Kidney Disease Section, Building 10, Room 3N-116, National Institute of Diabetes and Digestive and Kidney Diseases, Bethesda, MD 20892.

Received for publication 25 June 1990 and in revised form 12 December 1990.

1. Abbreviations used in this paper: $\mathrm{E}^{+}$and $\mathrm{E}^{-}$, erythrocyte rosetteforming and non-erythrocyte rosette-forming (cells); IL-2R, IL-2 receptor(s); NK, natural killer (cells).

The Journal of Clinical Investigation, Inc.

Volume 87, May 1991, 1739-1747 tinct polypeptide chains, each of which contains an IL-2 binding site $(1,3)$. The larger IL-2 binding protein $(75 \mathrm{kD})$ is designated as the $\beta$ chain, whereas the smaller protein $(55 \mathrm{kD}$, Tac antigen) is termed the $\alpha$ chain. Each chain reacts with IL-2 very differently; IL- 2 binds and dissociates from p75 $\beta$ chains slowly, whereas it reacts very rapidly with $\mathrm{p} 55 \alpha$ chains. When paired, these two lower-affinity ligand-binding proteins result in a very high-affinity IL-2 receptor. Interestingly, only binding of IL- 2 through the p75 $\beta$ chains stimulates T cell proliferation (1).

Synthesis of IL-2 and the IL-2R p55 chains is regulated at least in part at the level of DNA transcription $(2,4,5)$. However, the regulation of IL-2R p55 differs from the regulation of its ligand, IL-2: both an increase of cytoplasmic free calcium $\left[\mathrm{Ca}^{2+}\right]_{\mathrm{i}}$ and activation of protein kinase $\mathrm{C}$ are required to activate transcription of the IL-2 gene in resting $T$ cells. Reagents that activate protein kinase $\mathrm{C}$ are sufficient and more potent than those that only increase $\left[\mathrm{Ca}^{2+}\right]_{\mathrm{i}}$ in the induction of IL-2R p55 gene expression $(3,6)$. IL-2 itself up-regulates the expression of IL-2R p55 via a transcriptional mechanism $(7,8)$. The induction of IL-2R p55 expression by phorbol esters is not inhibitable by cyclosporine A, a potent inhibitor of IL-2 transcription (9). Taken together, these studies suggest that the regulation of IL-2 is more stringent than is the regulation of its receptor (10).

Dexamethasone, a synthetic glucocorticosteroid hormone, is a potent inhibitor of $\mathrm{T}$ cell proliferation induced by antigens and mitogens $(11,12)$. Dexamethasone inhibits the PHA-induced mRNA accumulation for IL-2 and IL-2R p55, as well as the IL-2 protein product and the expression of both the high-affinity and the low-affinity forms of IL-2R (11-14). However, previous investigations of the effect of dexamethasone on transcription of IL-2 and IL-2R p55 genes have relied either on unfractionated peripheral blood mononuclear cells (PBMC) (14), or on indirect methods, such as mRNA blotting, which do not distinguish between transcriptional and post-transcriptional effects $(11,14)$.

To date, the effects of dexamethasone on the nuclear transcription of IL-2 and IL-2R p55 genes have not been defined. We therefore investigated the effect of dexamethasone on the mitogen-induced expression of IL-2 and IL-2R p55 genes in pure human peripheral blood $\mathrm{T}$ cells by nuclear run-off assays, mRNA blotting, and determinations of the IL- 2 and p55 chain IL-2R gene products. Our data indicate that dexamethasone inhibits the nuclear transcription of IL-2 but not of the IL-2R gene. IL-2 gene expression is far more sensitive to the inhibitory effect of dexamethasone than is its receptor gene. Dexamethasone also decreases IL-2 expression by decreasing the stability of IL-2 mRNA. Finally, we present data suggesting that the inhibitory effect of dexamethasone on IL-2R p55 expression may be indirect, resulting from inhibition of IL-2 production. 


\section{Methods}

Mononuclear cells. PBMC were obtained and purified by gradient centrifugation over lymphocyte separation medium (Organon Teknica, Durham, NC) from leukapheresis of normal volunteers by the Department of Transfusion Medicine, Clinical Center, National Institutes of Health (NIH). Cells were aspirated from the resulting interface and washed three times in phosphate-buffered saline without $\mathrm{Ca}^{+2}$ or $\mathrm{Mg}^{+2}$.

Monocyte depletion. PBMC were depleted of macrophages by fractionation in Sepracell-MN (Sepratech, Oklahoma City, OK) according to the instructions of the manufacturer.

Erythocyte rosetting. Monocyte-depleted cells were further fractionated into sheep red blood cell (SRBC) rosette-forming $\left(\mathrm{E}^{+}\right)$cells and non-SRBC rosette-forming $\left(\mathrm{E}^{-}\right)$cells, using 2-aminoethylisothiouronium bromide-pretreated SRBC (Sigma Chemical Co., St. Louis, MO). Equal volumes of SRBC and mononuclear cell suspensions were incubated for $15 \mathrm{~min}$ at room temperature, spun down (200 $g$ for $5 \mathrm{~min}$ ), further incubated at $4^{\circ} \mathrm{C}$ for at least $2 \mathrm{~h}$, layered over lymphocyte separation medium cushions, and centrifuged for $30 \mathrm{~min}$ at $400 \mathrm{~g}$. The pellet containing the $\mathrm{E}^{+}$cells was collected and incubated at room temperature for $5 \mathrm{~min}$ with $10 \mathrm{ml}$ of red blood cell-lysing buffer (NIH Media Unit, Bethesda, MD) and then washed with phosphate-buffered saline three times.

Cell cultures. $\mathrm{E}^{+}$cells were resuspended at a density of $1-2 \times 10^{6}$ per $\mathrm{ml}$ in complete medium (RPMI-1640 supplemented with $10 \%$ heat-inactivated fetal calf serum, $2 \mathrm{mM}$ L-glutamine, and $25 \mu \mathrm{g} / \mathrm{ml}$ gentamicin) and were cultured in $5 \% \mathrm{CO}_{2} / 95 \%$ air at $37^{\circ} \mathrm{C}$ for various times with $2 \mu \mathrm{g} / \mathrm{ml}$ of PHA (Burroughs-Wellcome Co., Research Triangle Park, NC), $10 \mathrm{ng} / \mathrm{ml}$ of phorbol myristate acetate (PMA; Sigma Chemical Co.), $10^{-4}$ to $10^{-9} \mathrm{M}$ dexamethasone (Sigma Chemical Co.). In some experiments, we used $100 \mathrm{ng} / \mathrm{ml}$ of cyclosporin A (Sandoz, Basel, Switzerland), $10 \mu \mathrm{g} / \mathrm{ml}$ of actinomycin D (Sigma Chemical Co.), or 20 $\mathrm{U} / \mathrm{ml}$ of purified recombinant human IL-2 (Genzyme Corp., Boston, MA). Cells were preincubated with dexamethasone for $8 \mathrm{~h}$ and then washed three times before the addition of other reagents.

Proliferation assay. In brief, quadruplicate samples of $0.2 \mathrm{ml}$ of the final cell suspension were transferred to flat-bottomed 96-well microtiter plates and incubated at $37^{\circ} \mathrm{C}$ in $5 \% \mathrm{CO}_{2} / 95 \%$ air for $72 \mathrm{~h}$. Each well was pulsed with $0.5 \mu \mathrm{Ci}$ of $\left[{ }^{3} \mathrm{H}\right]$ thymidine (specific activity 6.7 $\mathrm{Ci} / \mathrm{mmol}$; New England Nuclear, Boston, MA), $16 \mathrm{~h}$ before termination of cultures. Data below are reported as mean \pm standard deviation of counts per minute (cpm) of cultures set in quadruplicate. $\mathrm{A}\left[{ }^{3} \mathrm{H}\right]-$ thymidine incorporation assay was performed with PBMC from each donor. Typical values for cell proliferation were as follows: PBMC alone, 210 \pm 17 ; PBMC with PHA, 42,000 2,450; PBMC with PHA and PMA, 57,800 $\pm 3,300$; PBMC with PHA and dexamethasone $\left(10^{-4}\right.$, $\left.10^{-5}, 10^{-6} \mathrm{M}\right), 600 \pm 58,7,300 \pm 500$, and $12,100 \pm 780$, respectively; PBMC with PHA in combination with PMA and dexamethasone $\left(10^{-4}, 10^{-5}, 10^{-6} \mathrm{M}\right), 720 \pm 65,8,100 \pm 730$, and $17,600 \pm 1225$, respectively. PBMC from individual donors were not used if $10^{-4} \mathrm{M}$ dexamethasone failed to inhibit their $\left[{ }^{3} \mathrm{H}\right]$ thymidine incorporation by at least $80 \%$.

Immunofluorescence and flow cytometry. A direct immunofluorescence assay was performed by using the following fluorescein isothiocyanate (FITC)-conjugated monoclonal antibodies: anti-B1 (Coulter Immunology, Hialeah, FL) detecting the B cell-specific surface marker B1; anti-Leu-M3 (Becton, Dickinson \& Co., Mountain View, CA) detecting monocytes, and anti-Leu 11a (Becton-Dickinson) detecting macrophage and natural killer (NK) cells, respectively. Immunofluorescence staining, coupled with fluorescence-activated cell sorter analysis, demonstrated that $95-98 \%$ of the $\mathrm{E}^{+}$cells bore the T cell-specific surface marker, Leu-4. For IL-2R expression, the anti-IL-2R (anti-Tac) monoclonal antibody $\left(\operatorname{IgG}_{1}\right)$ was used (Becton-Dickinson) which recognizes both the high- and low-affinity forms of the human receptor for IL-2 (p55 chain). Cells were analyzed by flow cytometry (EPICS Profile, Becton-Dickinson) by using log-scale amplification of the fluorescence signal. Nonspecific binding of IgG2a control antibody (BectonDickinson) was subtracted from specific values. The percentage of cells staining positively with anti-Tac or the change in the relative mean fluorescence intensity of Tac antigen expression on $\mathrm{E}^{+}$cells was determined.

IL-2 assay. The murine IL-2-dependent T cell line CTLL-2 was maintained in continuous culture with recombinant (r)IL-2. The cells were subcultured at a density of $10^{5}$ cells $/ \mathrm{ml}$ in complete medium (RPMI-1640 with $10 \%$ [vol/vol] fetal calf serum) and rIL-2 (2 U/ml). For the measurement of IL-2 activity in test supernatants, CTLL-2 cells $\left(10^{4} / 100 \mu \mathrm{l}\right)$ were cultured in quadruplicate in 96-well plates with complete medium and various dilutions of the supernatants. After $20 \mathrm{~h}$, cells were pulsed with $1 \mu \mathrm{Ci}$ of $\left[{ }^{3} \mathrm{H}\right]$ thymidine for an additional $4 \mathrm{~h}$ and harvested on glass fiber filters using an automatic cell harvester (LKB Produkter, Wallac Oy, Finland). Individual filters were placed in sample bags with liquid scintillation fluid (Pharmacia, Inc., Piscataway, NJ) and counted on a beta liquid scintillation counter (LKB Prodakter).

Soluble IL-2R assay. Soluble IL-2R were determined by a "sandwich" enzyme-linked immunosorbent assay (ELISA) which employs two monoclonal antibodies (anti-Tac and 7G7/B6) that recognize distinct epitopes on the human IL-2R as described (15). In brief, alternate rows of the inner 60 wells of flat-bottomed 96-well microtiter plates (Immulon-1, Dynatech Laboratories, Inc., Alexandria, VA) were coated overnight with $150 \mu \mathrm{l}$ of purified anti-Tac at $1 \mu \mathrm{g} / \mathrm{ml}$ in carbonate buffer, $\mathrm{pH} 9.6$, or carbonate buffer alone as a background control. After washing, $100 \mu \mathrm{l}$ of various dilutions of samples was added to the coated and control wells, incubated for $2 \mathrm{~h}$, and washed; $100 \mu \mathrm{l}$ of a 1/4,000 dilution of FITC-conjugated 7G7/B6 in phosphate-buffered saline containing $1 \%$ FCS was added to all the wells. After an additional 2-h incubation, the plates were washed, and $100 \mu \mathrm{l}$ of a $1 / 1,000$ dilution of alkaline phosphatase-conjugated rabbit anti-FITC was added. After a 1-h incubation, the plates were washed, $100 \mu \mathrm{l}$ of $p$-nitrophenyl phosphate $(1 \mathrm{mg} / \mathrm{ml}$, Sigma Chemical Co.) was added, and the absorbance of the wells was determined after $30 \mathrm{~min}$ at $405 \mathrm{~nm}$ by using a Titertek ELISA reader (Flow Laboratories, Inc., Rockville, MD). A reference reagent, consisting of the cell-free supernatant of a normal IL-2-dependent human $\mathrm{T}$ cell line, $4 \mathrm{~d}$ after stimulation with $10 \%$ IL-2 (Cellular Products, Buffalo, NY), was used in all of these studies. The undiluted supernatant was assigned a value of $1,000 \mathrm{IL}-2 \mathrm{R} \mathrm{U} / \mathrm{ml}$, and the absorbance values as determined by ELISA of serial dilutions of this supernatant were used to generate a reference curve. The absorbance of the test wells were then compared with the standard curve and were converted to a numerical value.

RNA isolation. Pelleted PBMC were lysed with a denaturing solution containing $4 \mathrm{M}$ guanidinium thiocyanate (Fluka, Buchs, Switzerland), $25 \mathrm{mM}$ sodium citrate, pH 7.0 (Mallinckrodt, Inc., Paris, KY), 0.5\% sarcosyl, and 0.1 M 2-mercaptoethanol (Sigma Chemical Co.), and homogenized immediately, as described (16). Briefly, 80-100 $\times 10^{6} \mathrm{E}^{+}$cells were lysed with $3 \mathrm{ml}$ of the denaturing solution, homogenized at room temperature, and transferred to a $12-\mathrm{ml}$ polypropylene tube. Subsequently, $0.3 \mathrm{ml}$ of $2 \mathrm{M}$ sodium acetate $(\mathrm{pH} 4.0), 3 \mathrm{ml}$ of phenol (water-saturated; Bethesda Research Laboratories, Gaithersburg, MD), and $0.6 \mathrm{ml}$ of chloroform-isoamyl alcohol mixture (49:1) were added to the homogenate. The final suspension was shaken vigorously for $10 \mathrm{~s}$, cooled on ice for $15 \mathrm{~min}$, and centrifuged at $10,000 \mathrm{~g}$ for 20 min at $4^{\circ} \mathrm{C}$.

The aqueous phase was collected in a new tube, mixed with 2 vol of absolute ethanol, and placed on dry ice for at least $20 \mathrm{~min}$ to precipitate RNA. This was followed by centrifugation at $10,000 \mathrm{~g}$ for $20 \mathrm{~min}$. The RNA pellet was dissolved in $0.5 \mathrm{ml}$ of the denaturing solution, transferred into a 1.5-ml Eppendorf tube, precipitated with 2 vol of absolute ethanol on dry ice for $20 \mathrm{~min}$, and centrifuged in an Eppendorf centrifuge for $10 \mathrm{~min}$ at $4^{\circ} \mathrm{C}$. The RNA pellet was resuspended in $75 \%$ ethanol, sedimented, vacuum-dried, dissolved in $40 \mu \mathrm{l}$ of $0.5 \%$ sodium dodecyl sulfate (SDS) at $65^{\circ} \mathrm{C}$ for $10 \mathrm{~min}$, and quantitated by absorbance at $260 \mathrm{~nm}$.

Northern blot analysis. Total RNA was denatured at $100^{\circ} \mathrm{C}$ for 2 min in an electrophoresis buffer (0.4 M 3-morpholino-propanesulfonic acid [Fluka], 0.1 M sodium acetate, 2 mM EDTA, pH 6.0 [Sigma 
Chemical Co.] containing 6\% formaldehyde [Mallinckrodt, Inc.] and $50 \%$ formamide [Mallinckrodt, Inc.]), and was size-fractionated by electrophoresis $(5 \mu \mathrm{g} / \mathrm{lane})$ through $1 \%$ agarose gels containing $6 \%$ formaldehyde. The gels were then stained with ethidium bromide to assure integrity of the loaded RNA. RNA was transferred to nylon membranes (Gene Screen Plus, New England Nuclear, Boston, MA) and baked for $2 \mathrm{~h}$ at $80^{\circ} \mathrm{C}$ in a vacuum oven. Membranes were prehybridized and hybridized with the following ${ }^{32} \mathrm{P}$-labeled complementary DNA probes: (a) a 700-bp fragment of IL-2 containing the StuI and Xbal sites of human IL-2 (Oncor, Gaithersburg, MD), (b) a 320-bp PstI-AvaII fragment of the fourth exon of human IL-2R (p55 chain, Oncor), and (c) 1.4-kb PstI fragment of a glyceraldehyde 3-phosphate dehydrogenase (GAPDH) (17) and human $\beta$-actin (Lofstrand Laboratories, Gaithersburg, MD) which served as control probes. They were hybridized in a solution containing 1\% SDS (Bio-Rad Laboratories, Richmond, CA), $1 \mathrm{M} \mathrm{NaCl}, 10 \%$ dextran sulfate (Pharmacia, Inc.), 50 $\mathrm{mM}$ Tris, pH 7.5 (Bethesda Research Laboratories), and $250 \mu \mathrm{g} / \mathrm{ml}$ salmon sperm DNA (Pharmacia, Inc.), at $65^{\circ} \mathrm{C}$ overnight. The filters were then washed twice with $2 \times$ SSC $(1 \times$ SSC $=0.015 \mathrm{M}$ sodium citrate, $0.15 \mathrm{M} \mathrm{NaCl}, \mathrm{pH} 7$ ) at $25^{\circ} \mathrm{C}$, twice with $2 \times \mathrm{SSC}$ and $1 \% \mathrm{SDS}$ at $65^{\circ} \mathrm{C}$, and twice with $0.1 \times \mathrm{SSC}$ at $25^{\circ} \mathrm{C}$ for $30 \mathrm{~min}$. They were then exposed to XAR-2 films (Eastman Kodak Co., Rochester, NY) at $-70^{\circ} \mathrm{C}$ in the presence of intensifying screens. After development, the intensities of the bands on the films were quantitated by scanning densitometry.

Nuclear run-off transcription assays. Nuclei were isolated by incubating the cells on ice in lysing solution containing $10 \mathrm{mM}$ Tris $(\mathrm{pH}$ 8.0), $10 \mathrm{mM} \mathrm{MgCl}$, $1 \mathrm{mM}$ dithiothreitol (DTT; Sigma Chemical Co.), and $0.1 \%$ Nonidet P40 (Sigma Chemical Co.) (18). The nuclei were then centrifuged, and the pellet was resuspended in lysis solution without NP40 containing $10 \mu \mathrm{g} / \mathrm{ml}$ RNase A (Bethesda Research Laboratories), incubated on ice for $20 \mathrm{~min}$, and then layered onto $30 \%$ sucrose in lysis solution and centrifuged at $400 \mathrm{~g}$ for $10 \mathrm{~min}$. The nuclei were counted, and $60-80 \times 10^{6}$ nuclei were incubated in $100 \mu$ l of a solution containing $70 \mathrm{mM} \mathrm{KCl}, 5 \mathrm{nM} \mathrm{MgCl}_{2}, 2 \mathrm{mM}$ DTT, $0.1 \mathrm{mM}$ EDTA, 0.5 $\mathrm{mM} \mathrm{MnCl}, 10 \mathrm{mM}$ Tris pH 8.0, $10 \%$ glycerol (Bethesda Research Laboratories), $0.4 \mathrm{mM}$ ATP, $0.4 \mathrm{mM}$ CTP, $0.4 \mathrm{mM} \mathrm{GTP}$ (Pharmacia, Inc.), $0.2 \mathrm{mCi}$ of ${ }^{32} \mathrm{P}$-labeled UTP $(800 \mathrm{Ci} / \mathrm{mmol}$; Amersham Corp., Arlington Heights, IL), and $2 \mathrm{U} / \mu \mathrm{l}$ RNasin (Promega Biotec, Madison, WI). The incubation was carried out for $20 \mathrm{~min}$ at $30^{\circ} \mathrm{C}$ with mixing. The reaction was terminated by adding $450 \mu \mathrm{g} / \mathrm{ml}$ of RNase-free DNase I (Bethesda Research Laboratories) and incubating for $5 \mathrm{~min}$ at $30^{\circ} \mathrm{C}$. The samples were then adjusted to $1 \%$ SDS, containing 15 mM EDTA, and incubated with $260 \mu \mathrm{g} / \mathrm{ml}$ proteinase K (Bethesda Research Laboratories) for $30 \mathrm{~min}$ at $40^{\circ} \mathrm{C}$; they were extracted twice with phenol and chloroform (1:1) and once with chloroform (Mallinckrodt, Inc.).

Labeled RNA was isolated in $0.25 \%$ SDS, $10 \mathrm{mM}$ Tris, and $2 \mathrm{mM}$ EDTA (pH 7.0) with a Centricon 30 microconcentrator (Amicon, Danvers, MA). Equal counts per minute of ${ }^{32} \mathrm{P}$-labeled RNAs were then heat-denatured and added to prehybridized nylon filters (Gene Screen Plus) in a solution containing $1 \%$ SDS, $1 \mathrm{M} \mathrm{NaCl}, 10 \%$ dextran sulfate (Pharmacia, Inc.), $50 \mathrm{mM}$ Tris (pH 7.5), $250 \mu \mathrm{g} / \mathrm{ml}$ salmon sperm DNA, and $100 \mu \mathrm{g} / \mathrm{ml}$ poly-(A) RNA (Pharmacia, Inc.) and were incubated at $65^{\circ} \mathrm{C}$.

Denatured plasmid DNAs (pBR322 plasmid DNA as a negative control, a 1.4-kb Pstl fragment of GAPDH in pBR322, a 0.94-kb Eco RI fragment of IL-2R p55 in pBR322 and the PstI fragment of human IL-2 in pBR322 [American Type Culture Collection, Rockville, MD]), equivalent to $0.5 \mu \mathrm{g}$ of insert DNA, were immobilized on nylon filters using a dot-blot apparatus (Bethesda Research Laboratories). After $2 \mathrm{~d}$ of hybridization, the filters were washed twice with $2 \times \mathrm{SSC}$ at $25^{\circ} \mathrm{C}$ twice with $2 \times \mathrm{SSC}$ and $1 \% \mathrm{SDS}$ at $65^{\circ} \mathrm{C}$ for $30 \mathrm{~min}$, once with $0.1 \times$ $\mathrm{SSC}$ at $25^{\circ} \mathrm{C}$ for $15 \mathrm{~min}$, and once with $2 \times \mathrm{SSC}$ with $1 \mu \mathrm{g} / \mathrm{ml}$ RNase A at $40^{\circ} \mathrm{C}$ for $10 \mathrm{~min}$. This was followed by one wash with $2 \times \mathrm{SSC}$ with $1 \%$ SDS at $65^{\circ} \mathrm{C}$ and two washes with $0.1 \times \mathrm{SSC}$ for $30 \mathrm{~min}$ at $25^{\circ} \mathrm{C}$. The filters were air dried and exposed to XAR-2 films with intensifying screens at $-70^{\circ} \mathrm{C}$ for $1-3 \mathrm{~d}$. Quantification of the data was performed by scanning densitometry within the linear range of the densitometer after substraction of background hybridization to pBR322. Values of gene transcription were then expressed relative to the constitutively transcribed control gene, GAPDH.

\section{Results}

IL-2 production. Previous reports have shown that dexamethasone inhibits the release of IL-2 into the supernatants of PHAstimulated human PBMC (11-13). As shown in Fig. 1 dexamethasone inhibits IL-2 production in a dose-dependent fashion. At high concentrations of dexamethasone $\left(10^{-4} \mathrm{M}\right), \mathrm{IL}-2$ production was suppressed by $100 \%$. At $10^{-6} \mathrm{M}$ there was $80 \%$ inhibition of IL-2 production. No inhibition was seen at $10^{-9}$ M (data not shown). This effect could not be explained by carryover of dexamethasone into the IL-2 assay, since after incubation of cells with dexamethasone, cells were washed three times with medium; addition of exogenous IL-2 to supernatants with low IL-2 activity reconstituted the response of the assay.

$I L-2 R$ p55 chain expression. Fig. 2 is representative of several experiments in which relative levels of expression of $\mathrm{p} 55$ chain of IL-2R (Tac antigen) were measured after 24-h cultures of $\mathrm{E}^{+}$cells in the presence of PHA and/or PMA and various concentrations of dexamethasone $\left(10^{-4}\right.$ to $\left.10^{-6} \mathrm{M}\right)$. At high concentrations of dexamethasone $\left(10^{-4} \mathrm{M}\right)$, IL-2R p 55 expression was inhibited by $\sim 50 \%$; lower concentrations of dexamethasone $\left(10^{-6} \mathrm{M}\right)$ still had demonstrable effects on IL-2R p55 expression. No inhibition was seen at $10^{-7} \mathrm{M}$ concentrations of dexamethasone when IL-2R p55 expression was assessed at $24 \mathrm{~h}$. However, longer incubation $(\geq 72)$ demonstrated significant inhibition at doses of dexamethasone as low as $10^{-8} \mathrm{M}$. No inhibition was seen at $10^{-9} \mathrm{M}$ even with prolonged incubation (data not shown). In order to determine whether the inhibition of IL-2R p55 expression indirectly resulted from decreased IL-2 production, PBMC were stimulated with PHA and high doses of dexamethasone $\left(10^{-4} \mathrm{M}\right)$ in the presence of IL-2 $(20 \mathrm{U} / \mathrm{ml})$. As shown in Fig. 3, in the presence of exogenous IL-2, there was no demonstrable inhibition of IL-2R p55 expression by dexamethasone.

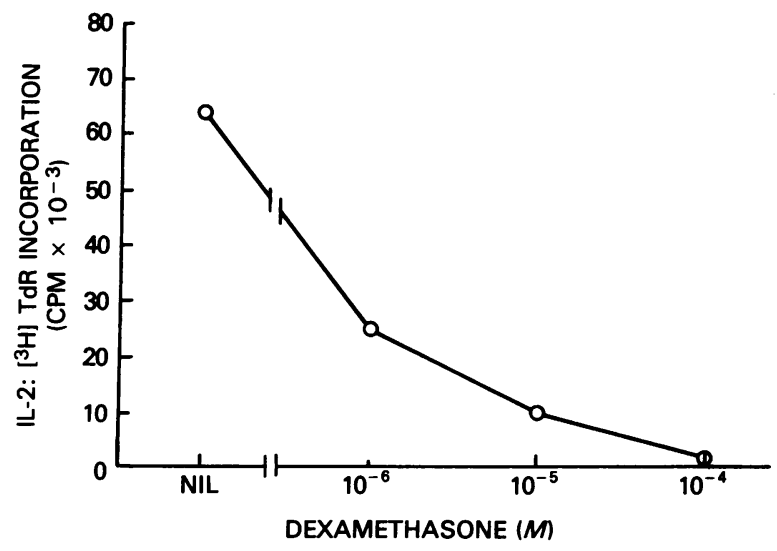

Figure 1. IL-2 activity in supernatants of E-rosette-positive human PBMC stimulated with PHA. Cells were exposed to various concentrations of dexamethasone for $8 \mathrm{~h}$ and washed with RPMI-1640 three times. Subsequently cells were stimulated with PHA $(2 \mu \mathrm{g} / \mathrm{ml})$ and cultured in RPMI-1640 with 10\% fetal calf serum for $24 \mathrm{~h}$. Supernatants were recovered and assayed for IL-2 in a mitogenic assay using the murine IL-2-dependent T cell line, CTLL-2, as described in Methods. Results represent the data from a representative experiment. 


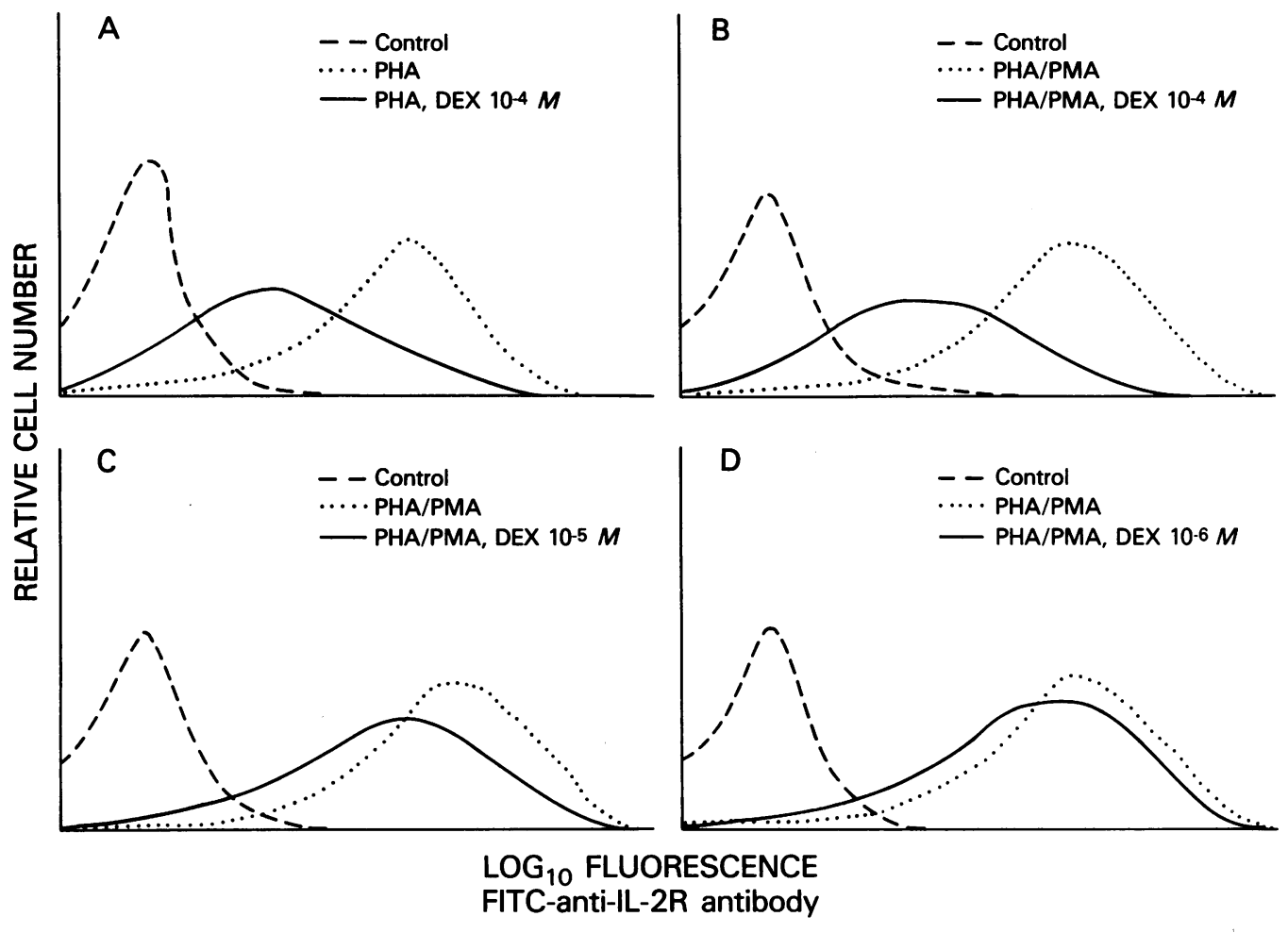

Figure 2. Dexamethasone inhibits IL-2R p55 chain expression in mitogen stimulated cultures of E-rosette-positive PBMC. Cells were stimulated with PHA $(2 \mu \mathrm{g} / \mathrm{ml})$ alone or in combination with PMA (10 $\mathrm{ng} / \mathrm{ml}$ ) for $24 \mathrm{~h}$ with or without dexamethasone; direct immunofluorescence assay was performed by using to fluorescein isothiocyanateconjugated monoclonal antibodies IL-2R (anti-Tac) and an IgG2a control antibody (see Methods for more details). Data shown are representative of five different experiments.
The duration of the inhibitory effect of dexamethasone on IL-2R p55 expression was assessed by the following experiment. $\mathrm{E}^{+}$cells were incubated for $8 \mathrm{~h}$ with dexamethasone $10^{-4}$ $M$, washed with medium three times in order to remove the unbound dexamethasone, and incubated for $3 \mathrm{~d}$ at $37^{\circ} \mathrm{C}$. Cells were subsequently stimulated with PHA and IL-2R p55 was determined 24, 48, and $72 \mathrm{~h}$ later. As shown in Fig. 4, the inhibitory effect of dexamethasone persisted for at least $72 \mathrm{~h}$ after incubation. Longer incubation periods were not carried out because of poor viability of unstimulated cells later in culture.

Soluble IL-2R. In addition to IL-2R expressed on the surface of $T$ cells, a soluble form of IL- $2 R$ is released, apparently

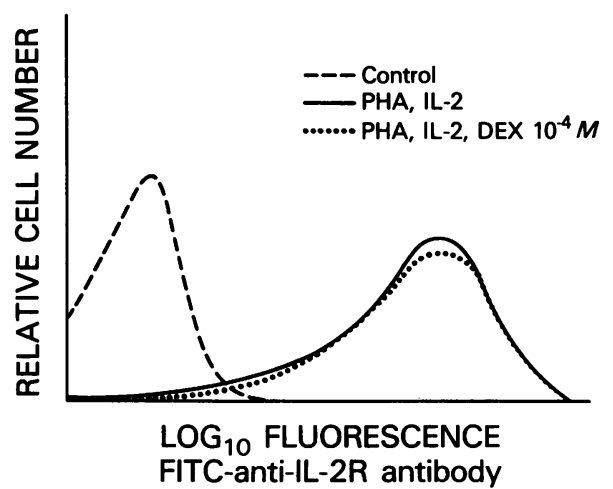

Figure 3. Exogenous IL-2 reverses the inhibitory effect of dexamethasone on IL-2R gene transcription. Cells were stimulated with PHA and rIL-2 $(20 \mathrm{U} / \mathrm{ml})$ in the presence or absence of dexamethasone and cultured for $24 \mathrm{~h}$ in complete medium. Immunofluorescence assay was then performed by using the anti-IL-2R p 55 antibody as described in Fig. 2. Data shown are representative of three different experiments. corresponding to a truncated form of the p55 chain of the cellassociated IL-2R. Soluble IL-2R has been shown to be present in the culture supernatants of activated normal lymphocytes as well as of tumor lines of T cell and B cell lineage (15). Supernatants of $24 \mathrm{~h}$ cultures of $\mathrm{E}^{+}$cells stimulated with PHA and/or PMA in the presence of various concentrations of dexamethasone $\left(10^{-4}\right.$ to $\left.10^{-6} \mathrm{M}\right)$, were assayed for soluble IL-2R by the "sandwich" ELISA, which employs two monoclonal antibodies, anti-Tac and 7G7B6, that recognize distinct epitopes on the human IL-2R (15). Dexamethasone inhibited the soluble IL-2R in the supernatants of cell cultures stimulated with PHA alone or with PMA. Fig. 5 shows the results from the quantitation of soluble IL-2R in the supernatants of $\mathrm{E}^{+}$cells cultured with PHA for $24 \mathrm{~h}$ in the presence of various concentrations of dexamethasone. Medium alone or medium with dexamethasone resulted in $<32 \mathrm{U} / \mathrm{ml}$ in our assay. As shown in Fig. 5, dexamethasone inhibited the release of soluble IL-2R in a dosedependent fashion.

$I L-2$ and $I L-2 R$ gene transcription. Having demonstrated dexamethasone inhibition of IL- 2 and IL-2R $\mathrm{p} 55$ chain production, we then investigated the mechanism underlying this effect. Since glucocorticosteroid hormones regulate the expression of several genes directly at a transcriptional level (19), we first examined the effects of dexamethasone on the transcription of IL-2 and IL-2R p55 genes by nuclear run-off assays. Previous investigations have shown maximum IL-2R gene induction to occur within the first $8 \mathrm{~h}$ after mitogenic stimulation of $\mathrm{E}^{+}$cells, whereas maximum induction of IL-2 gene occurs several hours later (20). We therefore examined the transcriptional activity of these genes at 8 and $24 \mathrm{~h}$ after mitogenic stimulation with PHA, or PHA and PMA. As shown in Fig. 6, dexamethasone $\left(10^{-4} \mathrm{M}\right)$ inhibited the transcription of the IL-2 gene at both 8 and $24 \mathrm{~h}$. Its inhibitory effect was most pronounced $(>80 \%)$ at $24 \mathrm{~h}$. Dexamethasone at a dose of $10^{-5} \mathrm{M}$ 


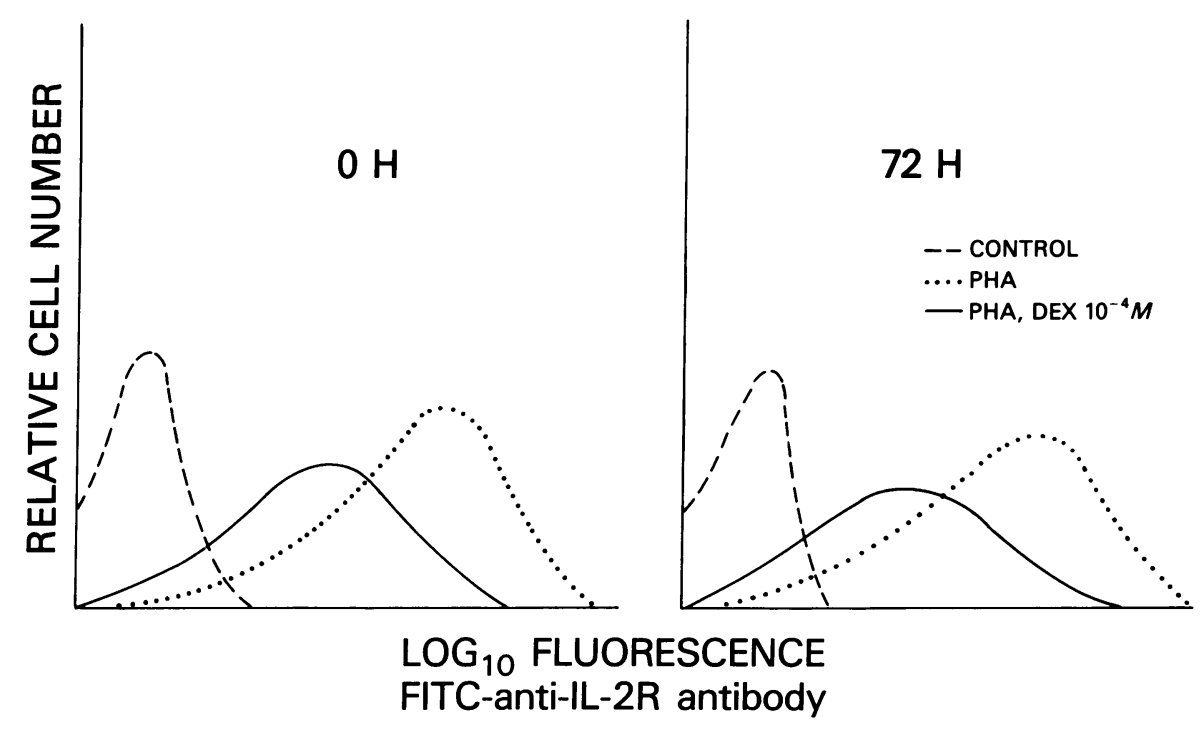

Figure 4. Prolonged inhibitory effect of dexamethasone on IL-2R p55 chain expression. Cells were preincubated with dexamethasone for $8 \mathrm{~h}$, washed three times, and stimulated with PHA immediately or after $72 \mathrm{~h}$ in culture with RPMI-1640. $(A)$ IL-2R p55 expression $24 \mathrm{~h}$ after stimulation with PHA which followed immediately after washing away dexamethasone. (B) IL2R p55 chain expression after PHA stimulation $72 \mathrm{~h}$ after incubation of cells with dexamethasone. IL-2R p55 expression was determined as described in Fig. 4. Data shown are representative of three different experiments. resulted in $\sim 60 \%$ inhibition, whereas a dose of $10^{-6}$ resulted in $\sim 25 \%$ inhibition of IL-2 gene transcription at $24 \mathrm{~h}$. Inhibition of IL-2 transcription was comparable in both PHA- and PHA/ PMA-stimulated T cells. No demonstrable effect was apparent at $10^{-7} \mathrm{M}$ dose of dexamethasone (data not shown).

In contrast to IL-2, nuclear transcription of IL-2R p55 at 8 and $24 \mathrm{~h}$ was not affected by the presence of even high dose dexamethasone $\left(10^{-4} \mathrm{M}\right)$, despite an $>80 \%$ inhibition of $\left[{ }^{3} \mathrm{H}\right]-$ thymidine incorporation, suggesting that dexamethasone does not exert inhibitory effects on IL- $2 R \beta$ chain production at a transcriptional level. However, after prolonged incubation of cells ( $\geq 48 \mathrm{~h}$ ) in the presence of dexamethasone, the transcriptional activity of IL-2R p55 was significantly inhibited (40$50 \%$ ). This is probably an indirect effect resulting from inhibition of IL-2 production which is known to increase the transcriptional activity of IL-2R p55 gene (8).

$I L-2$ and $I L-2 R$ mRNA accumulation. Resting $\mathrm{T}$ cells do not contain detectable IL-2 and IL-2R mRNA. IL-2 and IL-2R

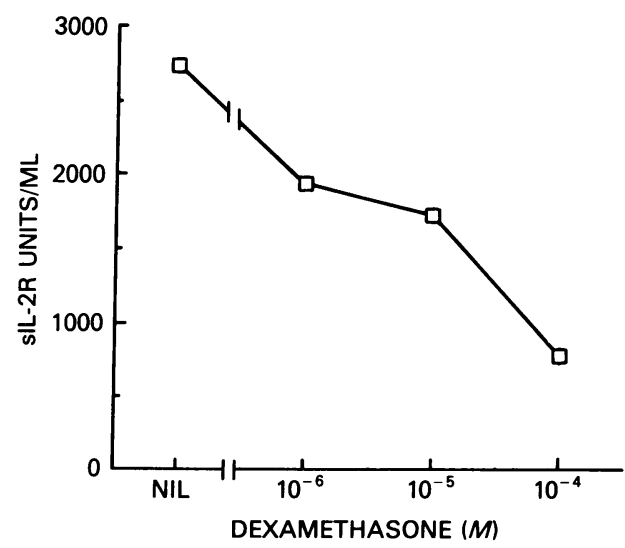

Figure 5. Dexamethasone inhibits the production of soluble(s) IL-2R in PHA-stimulated, E-rosette-positive PBMC. Cells were preincubated with dexamethasone for $8 \mathrm{~h}$, washed three times, stimulated with PHA $(2 \mu \mathrm{g} / \mathrm{ml})$, and cultured for $24 \mathrm{~h}$. Supernatants were collected and the soluble form of the IL-2R p55 chain was determined by an ELISA as described in Methods. Medium with or without dexamethasone resulted in $<32 \mathrm{U} / \mathrm{ml}$ in our assay.
mRNA appear within $8 \mathrm{~h}$ after stimulation, reach peak levels between 8 and $24 \mathrm{~h}$ and then decline $(4,11,21)$. The effect of dexamethasone on IL-2 and IL-2R mRNA accumulation were therefore studied at $9 \mathrm{~h}$, when mRNA accumulation was maximal. High doses of dexamethasone $\left(10^{-4} \mathrm{M}\right)$ resulted in $\sim 50 \%$ inhibition of IL-2R mRNA accumulation in a dose-dependent fashion (Fig. 7). No inhibition was seen at $10^{-6} \mathrm{M}$ dexamethasone. In contrast to IL-2R, high doses of dexamethasone $\left(10^{-4}\right.$ and $10^{-5}$ ) inhibited by $100 \%$ the IL- 2 mRNA accumulation; dexamethasone at a dose of $10^{-6}$ inhibited by $>70 \%$ the IL-2 mRNA. No inhibition of IL-2 mRNA was seen at $10^{-9} \mathrm{M}$ (data not shown).

IL-2 $m R N A$ stability. IL-2 gene expression is regulated at either the transcriptional level or post-transcriptionally by agents which affect the stability of IL-2 mRNA (22). The halflife of IL-2 mRNA in human peripheral blood T cells stimulated with anti-CD3 is short $\left(t_{1 / 2} \sim 45 \mathrm{~min}\right)(22)$. In the presence of PMA, a known stabilizer of lymphokine mRNA (23, 24), IL-2 half-life is $\sim 1-2 \mathrm{~h}(25)$. Since dexamethasone at $10^{-6}$ $M$ inhibited the nuclear transcription of IL-2 gene by $\sim 30 \%$, whereas its effect on IL-2 mRNA was more pronounced (70\% inhibition) suggesting the involvement of post-transcriptional mechanisms, we next examined the half-life of IL-2 mRNA in $T$ cells stimulated with PHA and PMA in the presence or absence of dexamethasone $\left(10^{-6} \mathrm{M}\right)$. Transcription was interrupted $8 \mathrm{~h}$ after stimulation by cyclosporin A $(100 \mathrm{ng} / \mathrm{ml})$ a specific inhibitor of lymphokine gene transcription $(9,25)$. The half-life of IL-2 mRNA was found to be $2.1 \pm 0.25 \mathrm{~h}$ (in three independent experiments) and decreased by $\sim 50 \%\left(t_{1 / 2}\right.$ $1.2 \pm 0.13 \mathrm{~h}$ ) in the presence of dexamethasone (Fig. 8). Actinomycin D $(10 \mu \mathrm{g} / \mathrm{ml})$, a nonspecific inhibitor of RNA transcription, failed to inhibit the transcription of IL-2 mRNA in prestimulated cells, but not in unstimulated cells (four independent experiments, data not shown). Similar experience has been reported by other investigators who have used comparable experimental conditions (25).

\section{Discussion}

IL-2 and its receptor play an essential role in T cell, B cell, and NK effector cell function and in thymocyte differentiation. In 
$8 \mathrm{H}$
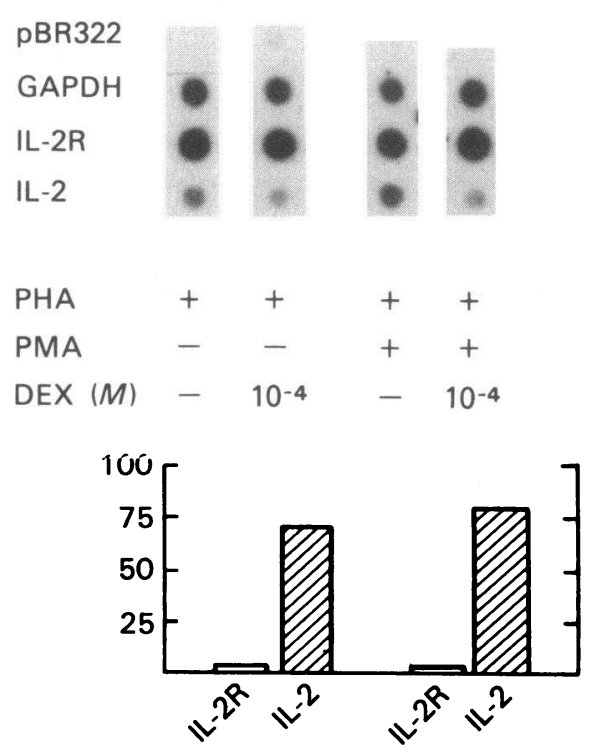

$24 \mathrm{H}$

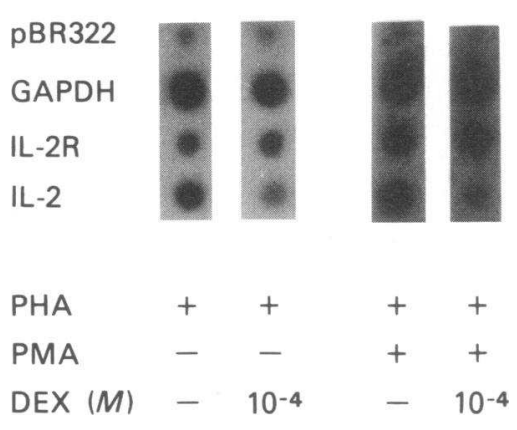

INHIBITION

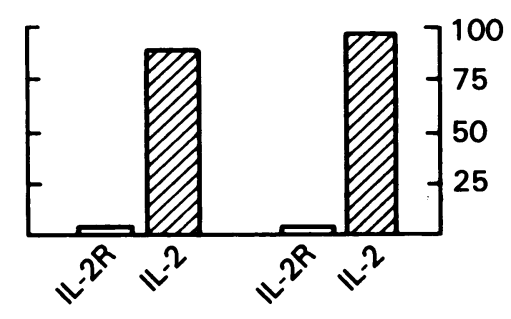

Figure 6. Effects of dexamethasone on the nuclear transcription of IL-2 and IL2R p55 genes. E-rosette-positive human PBMC were incubated with dexamethasone for $8 \mathrm{~h}$, washed, and stimulated with PHA $(2 \mu \mathrm{g} / \mathrm{ml})$ alone or with PMA (10 ng/ $\mathrm{ml})$. Nuclei were isolated 8 and $24 \mathrm{~h}$ later and transcription was performed using ${ }^{32}$ P-labeled UTP. Labeled RNA was then isolated and hybridized to nylon filters onto which pBR322,

GAPDH, IL-2, and IL-2R p55 plasmid cDNAs had been immobilized using a dot-blot apparatus. Comparable GAPDH signal ensures similar loading of samples. Results are representative of four experiments. addition to playing a major role in physiological immune responses against foreign antigens, IL-2 and IL-2R may also be implicated in autoimmune phenomena (22). The present studies demonstrate the inhibitory effects of dexamethasone on IL-2 and IL-2R gene expression and their mechanisms. Dexamethasone inhibits the nuclear transcription and the mRNA accumulation of IL-2 whereas its effect on IL-2R is post-transcriptional and requires the presence of suprapharmacologic concentrations of dexamethasone. Addition of exogenous IL-2 neutralizes the inhibitory effect of dexamethasone on IL-2R gene expression. This suggests that its inhibitory effect is probably indirect, resulting from decreased IL-2 production.

Steroid hormones are known to regulate directly the expression of many eukaryotic genes at the transcriptional level (19). In addition to their transcriptional effects, steroid hormones have been reported to exert nontranscriptional effects by increasing the stability of mRNA (26), or the translational efficiency and the stability of hormone-induced proteins $(27,28)$.
IL-2R

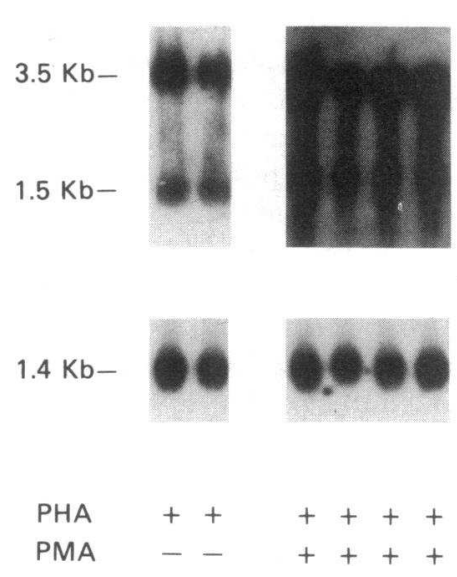

IL-2

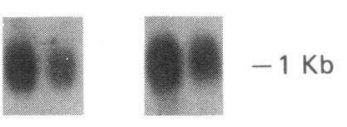

GAPDH

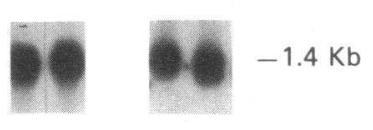

$+++$

$-++$

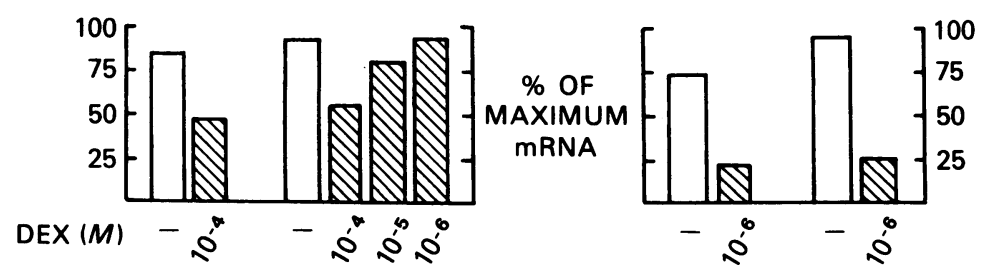

Figure 7. Effects of dexamethasone on IL-2R and IL-2 mRNA accumulation. Human peripheral blood $T$ cells were exposed to various concentrations of dexamethasone and stimulated with PHA $(2 \mu \mathrm{g} / \mathrm{ml})$ alone or with PMA (10 ng/ml) for $8 \mathrm{~h}$. Total cellular RNA was isolated, and size fractionated through a $1 \%$ agarose gel with formaldehyde and blotted onto a nylon membrane as outlined in the Methods. Membranes were probed with ${ }^{32} \mathrm{P}$-labeled cDNA probes for IL-2R p55 chain, IL2, and GAPDH. Equal loading and transfer of RNA onto membranes was ensured by identical UV-induced ethidium bromide fluorescence of ribosomal $18 \mathrm{~S}$ and $28 \mathrm{~S}$ bands and equal amounts of GAPDH signal. After development the intensities of the bands on the films were quantitated by scanning densitometry and expressed relative to the constitutively transcribed control gene, GAPDH. Densitometry data are expressed as the percentage of the PHA-induced response without dexamethasone. Results are representative of two different experiments. 

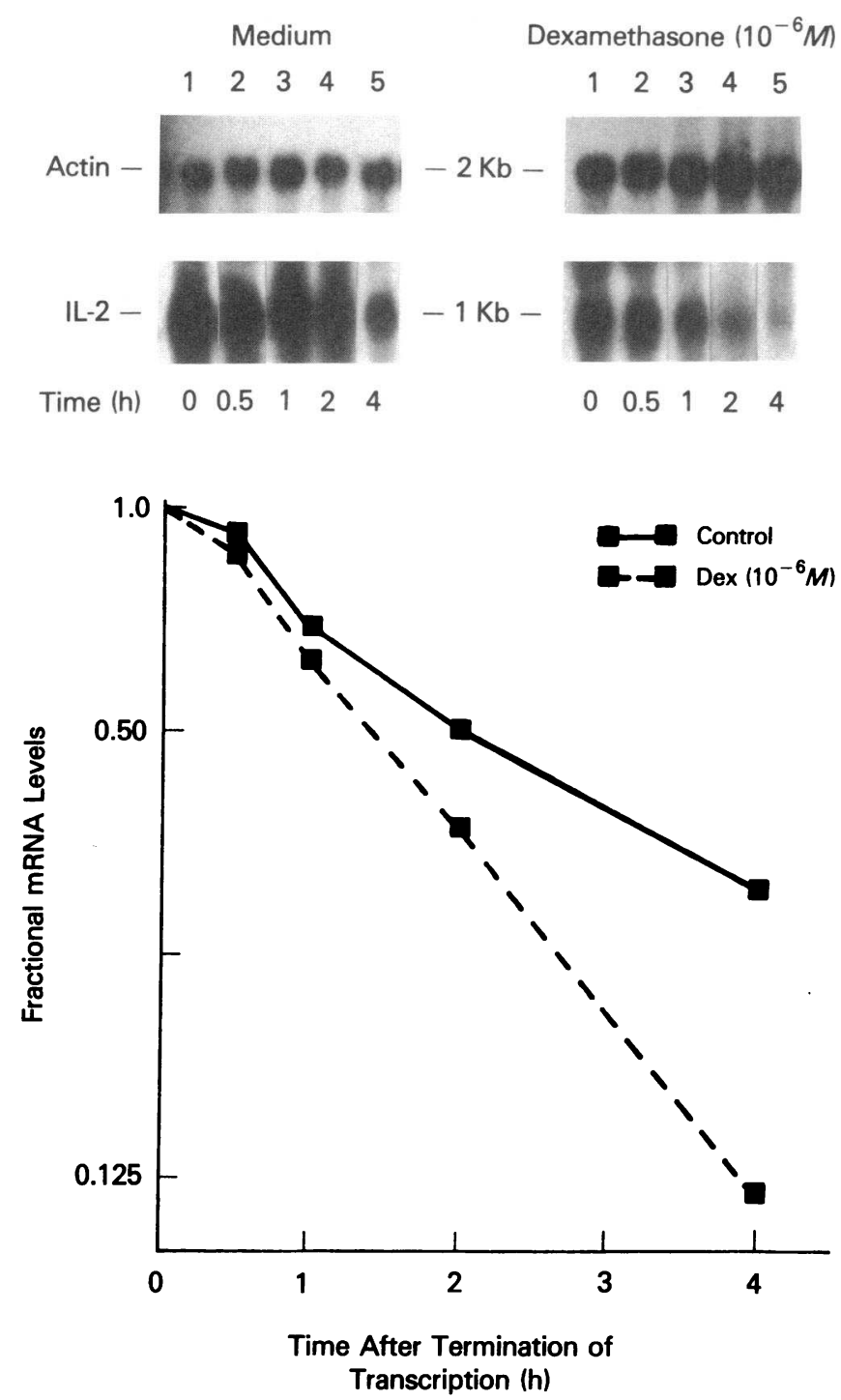

Figure 8. Dexamethasone decreases the stability of IL-2 mRNA. T cells were exposed to dexamethasone $\left(10^{-6} \mathrm{M}\right)$ and then stimulated with PHA $(2 \mu / \mathrm{ml})$ and PMA $(10 \mathrm{ng} / \mathrm{ml})$ for $8 \mathrm{~h}$. Cyclosporine A $(100 \mathrm{ng} / \mathrm{ml})$ was added and total cellular RNA was isolated $0,0.5,1$, 2 , and $4 \mathrm{~h}$ later. Northern blots were prepared from the RNA samples and hybridized with ${ }^{32} \mathrm{P}$-labeled cDNA probes for IL-2 and $\beta$-actin genes. After development, the intensities of the bands on the films were quantitated by scanning densitometry and expressed relative to the constitutively transcribed control gene, $\beta$-actin. Individual values for the zero points (IL-2/actin) were 1.60 without dexamethasone and 0.53 in the presence of dexamethasone. The amount of mRNA at the various times is expressed as a fraction of the mRNA level at time zero. The data presented are representative of these independent experiments.

According to the current paradigm, glucocorticoids exert their cellular effects by binding to intracellular receptors which subsequently bind to specific DNA regulatory elements (glucocorticoid-responding elements, GRE). It is believed that differences in nucleotide sequences are important in determining whether induction or repression of the gene will occur (29). In other cases, glucocorticoid repression seems to be mediated by a competition between the hormone receptor and other pro- teins for binding to overlapping DNA regulatory sequences. In these cases it is not the nucleotide sequence of a particular site that determines its positive or negative effect on transcriptional efficiency but rather the particular location of the binding site in relation to the sequence regulator (30).

Detailed analysis of the regulation of the IL-2 gene has demonstrated that a 276-bp segment upstream from the transcription initiation site contains the sequences that regulate its transcriptional activation $(31,32)$. This region is responsive to the synergistic actions of stimuli which increase $\left[\mathrm{Ca}^{2+}\right]_{i}$ and induce the activation of protein kinase $C(28)$. These two events will in turn stimulate the production of as yet unidentified gene products which may bind to the IL-2 regulatory region or influence the binding of other regulatory proteins to this sequence (33, $34)$. In contrast to B cells, where glucocorticoids suppress the anti-Ig antibody-induced calcium mobilization (35), glucocorticoids do not inhibit the PHA induced $\left[\mathrm{Ca}^{2+}\right]_{i}$ response in $\mathrm{T}$ cells (H. Yamada and D. T. Boumpas, unpublished data). It is conceivable therefore that the inhibitory effect of dexamethasone on PHA-induced IL-2 transcription could be attributed to inhibition of the activation of protein kinase $\mathrm{C}$ or to more distant sites of the $\left[\mathrm{Ca}^{2+}\right]_{\mathrm{i}}$ pathway (e.g., calmodulin). Remondo et al. (36) have suggested that inhibition of IL-2 induced proliferation of cloned murine $T$ cells by glucocorticoids may in part be due to inhibitory protein(s) which suppress DNA synthesis and the IL-2-induced growth of these cells (36). Similarly, glucocorticoid-induced new proteins could interfere with the induction of IL-2 gene and its regulation. Alternatively, glucocorticoid repression of IL-2 transcription could be mediated by a competition between the hormone receptor and other proteins for binding to overlapping DNA regulatory sequences (30).

Transcriptional induction of the gene encoding the $\alpha$-subunit of IL-2R has been shown to be mediated by a sequence element that is homologous to the nuclear factor $-\kappa \mathrm{B}$ binding site of the immunoglobulin kappa gene enhancer (37). More recently an additional sequence motif located $\sim 10$ bp downstream of the previously identified site has been described. Proteins binding at both sites act coordinately, leading to maximal induction of the IL-2R p55 gene (37). IL-2R gene expression is regulated at the level of transcription and agents that activate protein kinase $\mathrm{C}$ only are sufficient and more potent than those that increase $\left[\mathrm{Ca}^{2+}\right]_{\mathrm{i}}$ only to induce IL-2R p55 expression (6). The observed difference in the sensitivity to the inhibitory effect of dexamethasone between the IL-2 and IL-2R confirms previous reports for independent regulation of these genes.

RNA synthesis of PHA-stimulated peripheral blood lymphocytes is regulated by IL-2 (12). IL-2 augments the transcription of several genes including IL-2R, c-myc, and c-myb $(8,38$, 39). Inhibition of IL-2 production by dexamethasone does not interfere with the onset of RNA synthesis and T lymphocyte activation but rather inhibits subsequent events thereby arresting cells in the Gla phase. Addition of exogenous IL-2 in the cultures reverses the inhibitory effect of dexamethasone by allowing cells to synthesize more RNA (12). Our data on IL-2R p55 expression, whereby in the presence of exogenous IL-2 the expression of IL-2R p55 is not inhibited by dexamethasone, echo these findings and suggest that the inhibitory effects of dexamethasone on IL-2R expression is at least in part indirect, resulting from decreased IL-2 production.

The inhibitory effect of dexamethasone on IL-2 and IL-2R 
mRNA accumulation is in agreement with previous reports (14). Reed et al. (14) first observed that, whereas dexamethasone $\left(10^{-6} \mathrm{M}\right)$ significantly reduced the levels of IL-2 mRNA in PHA-stimulated peripheral blood mononuclear cells, it had no effect on IL-2R mRNA accumulation. Our data confirm their observations and offer a possible explanation for this phenomenon based on the lack of inhibition of IL-2R gene nuclear transcription by dexamethasone. The observed decrease in mRNA accumulation of IL-2R gene at higher doses of dexamethasone $\left(\geq 10^{-5} \mathrm{M}\right)$ probably is nonspecific and reflects a more generalized inhibition by dexamethasone of the completion of RNA synthesis (12).

The finding that dexamethasone can alter the stability of IL-2 mRNA is novel. In addition to transcriptional post-transcriptional mechanisms have been implicated in the regulation of IL-2 gene expression $(22,25)$. Addition of protein synthesis inhibitors can stabilize the IL-2 mRNA which is normally degraded by a labile $R$ Nase and thereby lead to its superinduction $(4,40)$. IL-2 mRNA has at least three reiterated copies of the sequence, AUUUA, which is known to confer instability to mature mRNAs $(22,41)$. Dexamethasone could change the stability of IL-2 mRNA either by inducing the synthesis of RNases or by increasing the number of AUUUA sequences in the IL-2 mRNA.

A major objective in glucocorticosteroid management of patients with immune mediated diseases is the reduction of side effects associated with their use. Alternate day glucocorticosteroid therapy has been reported to decrease significantly both the incidence and the severity of several of these complications, while at the same time being efficacious (42). The duration of the inhibitory effect of dexamethasone on $T$ cells (at least $72 \mathrm{~h}$ after the initial exposure of cells) suggests a basis for previous observations on the effectiveness of alternate day steroid therapy.

In conclusion, these studies have begun to elucidate some of the mechanisms involved in inhibition of IL-2 and its receptor by dexamethasone. By using dexamethasone as a research tool useful information may be obtained regarding the regulation of the expression of IL-2 and IL-2R genes with obvious clinical implications. Further studies are warranted to delineate the mechanism of action of corticosteroids on $\mathrm{T}$ cell gene expression.

\section{Acknowledgments}

The authors thank Ms. Lisa Miller for typing the manuscript and Dr. Hidehiro Yamada for critical review of the manuscript.

This work was supported in part by a grant from the Lupus Foundation of Washington, DC.

\section{References}

1. Smith, K. A. 1988. Interleukin-2: inception, impact and implications. Science (Wash. DC). 240:1169-1176.

2. Leonard, W. J., M. Krönke, N. J. Peffer, J. M. Depper, and W. C. Greene. 1985. Interleukin-2 receptor gene expression in normal T lymphocytes. Proc. Natl. Acad. Sci. USA. 82:6281-6285.

3. Waldmann, T. A. 1986. The structure, function and expression of interleukin-2 receptors on normal and malignant lymphocytes. Science (Wash. DC). 232:727-732.

4. Efrat, S., and R. Kames. 1986. Control of biologically active interleukin-2 messenger RNA formation in induced human lymphocytes. Proc. Natl. Acad. Sci. USA. 81:2601-2605.
5. Weiss, A., J. Imboden, K. Hardy, B. Manger, C. Terhorst, and J. Stobo. 1986. The role of the T3/antigen receptor complex in T cell activation. Annu. Rev. Immunol. 4:593-619.

6. Cross, S. L., M. B. Feinberg, J. B. Wolf, N. J. Holbrook, F. Wong-Staal, and W. J. Leonard. 1987. Regulation of the human interleukin-2 receptor $\alpha$ chain promoter: activation of a nonfunctional promoter by the transactivator gene of HTLV-1. Cell. 49:47-56.

7. Smith, K. A., and D. A. Cantrell. 1985. Interleukin 2 regulates its own receptors. Proc. Natl. Acad. Sci. USA. 82:864-868.

8. Depper, J. M., W. J. Leonard, C. Drogula, M. Krönke, T. A. Waldmann, and W. C. Greene. 1985. IL-2 augments transcription of the IL-2 receptor gene. Proc. Natl. Acad. Sci. USA. 82:4230-4234.

9. Krönke, M., W. J. Leonard, J. M. Depper, S. K. Arya, F. Wong-Staal, R. C. Gallo, T. A. Waldmann, and W. C. Greene. 1984. Cyclosporine inhibits T-cell growth factor gene expression at the level of mRNA transcription. Proc. Natl. Acad. Sci. USA. 81:5214-5218.

10. Weiss, A. 1989. T lymphocyte activation. In Fundamental Immunology. W. E. Paul, editor. Raven Press, New York. 359-384.

11. Arya, S. K., F. Wong-Staal, and R. C. Gallo. 1984. Dexamethasone mediated inhibition of human $\mathrm{T}$ cell growth factor and $\boldsymbol{\gamma}$-interferon messenger RNA. J. Immunol. 133:273-276.

12. Bettens, F, F. Kristensen, C. Walker, U. Schwulera, G. D. Bonnard, and A. L. De Weck. 1984. Lymphokine regulation of activated (G1) lymphocytes. II. Glucocorticoid and anti-Tac induced inhibition of human $T$ lymphocyte proliferation. J. Immunol. 132:261-265.

13. Gillis, S., G. R. Crabtree, and K. A. Smith. 1979. Glucocorticoid-induced inhibition of $\mathrm{T}$ cell growth factor production: Effect on mitogen-induced lymphocyte proliferation. J. Immunol. 123:1624-1628.

14. Reed, J. C., A. H. Abide, J. D. Alpers, R. G. Hoover, R. J. Robb, and P. C. Nowell. 1986. Effect of cyclosporin A and dexamethasone on interleukin 2 receptor gene expression. J. Immunol. 137:150-154.

15. Rubin, L. A., C. C. Kurman, M. E. Fritz, W. E. Biddison, B. Boutin, R Uarchoan, and D. L. Nelson. 1985. Soluble interleukin 2 receptors are released from activated human lymphoid cells in vitro. J. Immunol. 135:3172-3177.

16. Chomczynski, P., and N. Sacchi. 1987. Single step method of RNA isolation by acid guanidinium thiocyanate - phenol - chloroform extraction. Anal Biochem. 162:156-159.

17. Piechaczyc, M., J. M. Blanehard, L. Marty, C. Dami, F. Panabieres, E. S Elsabouty, P. Fort, and P. Jeunterur. 1984. Post-transcriptional regulation of glyceraldehyde-3-phosphate dehydrogenase gene expression in rat tissues. $\mathrm{Nu}$ cleic Acids Res. 12:6951-6956.

18. Dony, C., M. Kessel, and P. Gruss. 1985. Posttranscriptional control of myc and $\mathrm{p} 53$ expression during differentiation of embryonal carcinoma cell lines F9. Nature (Lond.). 317:636-641.

19. Ringold, G. M. 1985. Steroid hormone regulation of gene expression Annu. Rev. Pharmacol. Toxicol. 25:529-566.

20. Krönke, M., W. J. Leonard, J. M. Depper, and W. C. Green. 1985. Sequential expression of genes involved in human $\mathrm{T}$ lymphocyte growth and differentiation. J. Exp. Med. 16:1593-1598.

21. Leonard, W. J., M. Krönke, N. J. Peffer, and W. C. Green. 1985. Interleukin 2 receptor gene expression in normal human T lymphocytes. Proc. Natl. Acad. Sci. USA. 82:6281-6285.

22. Lindsten, T., C. H. June, J. A. Ledbetter, G. Stella, and C. B. Thompson. 1989. Regulation of lymphokine messenger RNA stability by a surface-mediated T cell activation pathway. Science (Wash. DC). 24:339-343.

23. Young, H. A., M. Birchenall-Sparks, E. Kovacs, L. Rodman, and F. N. Ruscetti. 1988. Characterization of interleukin 2 and phorbol myristate acetate augmentation of expression of transfected human interferon- $\gamma$ genomic DNA. $J$. Interferon Res. 8:527-538.

24. Bickel, M., R. B. Cohen, and D. H. Pluznik. 1990. Post-transcriptional regulation of granulocyte-macrophage colony-stimulating factor synthesis in murine T cells. J. Immunol. 145:840-845.

25. Shaw, J., K. Meerovitch, R. C. Bleackley, and V. Paetkau. 1988. Mechanisms regulating the level of IL-2 mRNA in T lymphocytes. J. Immunol. 140:2243-2248.

26. Robins, D. M., and R. T. Schimke. 1978. Differential effects of estrogen and progesterone on ovalbumin mRNA utilization. J. Biol. Chem. 253:89258934.

27. Ali, M., and W. V. Vederkis. 1987. The glucocorticoid receptor protein binds to transfer RNA. Science (Wash. DC). 235:467-470.

28. Kern, J. A., R. J. Lamb, J. C. Reed, R. P. Daniele, and P. C. Nowell. 1988 Dexamethasone inhibition of interleukin 1 beta production by human monocytes: post-transcriptional mechanisms. J. Clin. Invest. 81:237-244.

29. Kroemer, G., and G. Wick. 1989. The role of interleukin 2 in autoimmunity. Immunol. Today. 10:246-251.

30. Beato, M. 1989. Gene regulation by steroid hormones. Cell. 56:335-344.

31. Fujita, T., H. Shibuya, T. Ohashi, K. Kamanishi, and T. Taniguchi. 1986. 
Regulation of human interleukin-2 gene: functional DNA sequences in the 5 flanking region for the gene expression in activated T lymphocytes. Cell. 46:401407.

32. Durand, D. B., M. R. Rush, J. G. Morgans, A. Weiss, and G. R. Crabtree. 1987. A 275-base pair fragment at the $5^{\prime}$ end of the interleukin 2 gene enhances expression from a heterologous promoter in response to signals from the T-cell antigen receptor. J. Exp. Med. 165:395-407.

33. Shaw, J. P., P. J. Uts, D. B. Durand, J. J. Toole, E. A. Emmel, and G. R. Crabtree. 1988. Identification of a putative regulator of early $\mathrm{T}$ cell activation genes. Science (Wash. DC). 241:202-205.

34. Weiss, A., R. Shields, M. Newton, B. Manager, and J. Imboden. 1987. Ligand-receptor interactions required for commitment of the activation of the interleukin 2 gene. J. Immunol. 304:445-447.

35. Dennis, G., C. H. June, J. Mizuguchi, J. Ohara, K. Witherspoon, F. D. Finkleman, V. McMillan, and J. J. Mond. 1987. Glucocorticoids suppress calcium mobilization and phospholipid hydrolysis in anti-Ig antibody-stimulated B cells. J. Immunol. 139:2516-2523.

36. Remondo, J. M., M. Fresno, and A. Lopez-Rivas. 1988. Inhibition of interleukin 2-induced proliferation of cloned murine $\mathrm{T}$ cells by glucocorticoids: possible involvement of an inhibitory protein. Eur. J. Immunol. 18:1555-1559.

37. Pomerantz, J. L., M. Fabienne, M. Yoshida, W. C. Green, and R. Sen. 1989. A second element located $3^{\prime}$ to the NF-KB-binding site regulated IL-2 receptor- $\alpha$ gene induction. J. Immunol. 143:4275-4281.

38. Reed, J. C., D. Sabath, R. G. Hoover, and M. B. Prystowsky. 1985. Recombinant interleukin 2 regulated level of c-myc mRNA in a cloned T lymphocyte. Mol. Cell. Biol. 5:3361-3368.

39. Kelly, K., and U. Siebenlist. 1988. Mitogenic activation of normal T cells leads to increased initiation of transcription in the c-myc locus. J. Biol. Chem. 263:4828-4831.

40. Shaw, J., K. Meerovitch, J. C. Elliot, R. C. Bleackley, and V. Paetkau. 1987. Induction suppression and superinduction of lymphokine mRNA in lymphocytes. Mol. Immunol. 24:409-419.

41. Shaw, G., and R. Kames. 1986. A conserved AU sequence from the $3^{\prime}$ untranslated region of GM-CSF mRNA mediated selective degradation. Cell. 46:659-666.

42. Axelrod, L. 1976. Glucocorticoid therapy. Medicine (Baltimore). $55: 39-65$. 